\author{
Jan Danek $^{1}$, B.K. Shaushekova ${ }^{2}$, E.S. Ibrayeva ${ }^{2 *}$ \\ ${ }^{I}$ University of Saints Cyril and Methodius, Slovakia \\ ${ }^{2}$ Karagandy university of the name of academician E.A.Buketov, Kazakhstan \\ (Corresponding author's e-mail: ibraeva.es@gmail.com) \\ ORCID ID: 0000-0002-1428-7095
}

\title{
Advantages of joint work of school with organizations of supplementary education at different historical stages
}

\begin{abstract}
Article deals with the problem of interaction of the museum and school from the early ages. Authors give thoroughly full images of joint work of museums and schools in developed countries and analyze their experiences in conducting this way of cooperation. In the article there were listed the problems of interaction between the museum and the school and features of interaction at different historical stages. Authors describe the promising models of cooperation and the answers to question 'How the problem of "museum and school" is solved abroad?' Work of museums with students have been discussed in details, i.e. work with preschoolers and younger students, middle and high school students. Authors gave classification of museums of educational institutions: university museums, school museums, pedagogical museums. They have considered pedagogical museums in the period of origin and prosperity, the evolution of pedagogical museums, museums of the history of education and children's museums. Authors have analyzed the prospective of having museumschool partnership.
\end{abstract}

Keywords: museum, school, educational museums, school museums, interaction, interaction of institutions, learning environment, learning process.

\section{Introduction}

People are used to think that the museum and the school are completely different but a little interconnected. One or two collective attendance per year is enough for a report on extracurricular activities. The fact that the museum can bring tangible benefits to the teacher and his lesson, many of the teachers do not even realize. The museum is an invaluable educational resource, incomparable with anything in richness, which so far, unfortunately, few people use.

At present, close relations between the museums and the schools and other kind of collaborations are not reflected in the country. The museums function is separately apart from all educational institutions including secondary comprehensive schools. Schoolchildren visit the museums once a year and since we have only 3 museums in one city it is obvious that schoolchildren learnt by heart all exhibitions of every single museum. There are historical museums or museums dedicated to famous person in our country. This situation takes place not only in the city but in the whole country.

The interaction of the museum and the school (the latter is widely understood as the connection of all levels of education) is determined by the commonality of the tasks to be solved and, at the same time, the specifics of their implementation by each of these social institutions. The ideas about the purpose and ways of cooperation between the museum and the school has changed depending on the prevailing ideology and educational concepts. However, the museum and the school have always influenced each other, although sometimes their relationship was not without drama.

\section{Literature review}

The problems of the emergence, development and use in the educational process of school museums are studied quite widely, starting from the turn of the 19th and 20th centuries. So in the works of J. Borin, and. M. Graves, A.U. Zelenko, A. Likhtvarka, N. A. Khitkov, and others reveal the specifics of the museum's work with children's audience. In the works of I. Tumanov, M. Yu. Yukhnevich there was generalized experience in school museums, devoted to the goals, objectives and forms of their activities. In the works of K.D. Ushinsky, A.S.Makarenko, V.A.Sukhomlinsky the basic pedagogical principles and approaches substantiated that are used in the activity of school museums.

The historiographic review of scientific research in the field of museum pedagogy suggests that there is no single point of view on the question of exactly where school museums first appeared. The school museum of the turn of the 19th and 20th centuries, to a much lesser extent than any other, was a collection of rarities. 
N.A. Khitkov, the author of one of the first monographs on such museums, wrote that a school museum cannot be used to mean such an institution, where certain rarities are collected, because they are only desirable but not necessary in the school museum. A school museum is just a gathering of collections, devices, paintings and in general everything that is used everyday in a school where visual teaching is introduced, so the program of such a museum should be the most extensive and diverse.

Another researcher of this period noted that any object could be valuable for such a museum: "a stone lying on the road .... a box of matches ... an old nest of birds, a bumblebee, a growth on a tree, a sink, a button", as long as he became an object of close observation and a means of cognition of the environment. Particular importance in the collection of materials was attached to the connection with local conditions, with local history.

Y. Borin noted that in addition to the fact that the museum in the school was a condition for the development of skills useful and necessary for life, for raising curiosity, for building correct ideas and concepts about life around him, he was a way to establish contacts, inspire the teacher's relationship with children, also served as "an excellent impetus for further self-education and the teacher himself".

A.U. Zelenko was the author of an unrealized project of the Children's Museum-Palace, the concept of which at that time had no analogues. Based on the fact that the child learns the world through all the senses, and his joy "from the first seen, felt, smell, tried incomparably brighter than in adults, and the need for such sensations is stronger," he believed that the children's museum "should come up to children, primarily through sensory literacy. "Everything in it should be arranged so that the children have a burning desire to see, hear, feel, try, and also make discoveries and do something with their eyes.

F.I.Schmit believed that the educational museum is a workshop where "originals can be replaced with casts, copies, models, photographs of monuments." Simultaneously with the fact that the children's museum as an educational option is a workshop, educational space, a place for the child's activity to manifest, according to the plan of F.I.Schmit it is of value as a center for studying the psychology of children's creativity.

Thus, the school museum was most directly involved in the educational process for the implementation of a visual method of teaching, acquaintance with reality, with the requirements of the surrounding life. Another distinctive feature of it was that it was, as a rule, the fruit of joint efforts, joint creativity of students and teachers, who together were engaged in the collection or production of manuals.

Firstly, we will have a look at the history of museums in the United States. Museums in England have had a tremendous impact on museum building in the United States. The example of the South Kensington Museum was the basis of the educational concept of museums in New York, Boston, Chicago and other cities, which clearly demonstrated the museum's use of art exhibitions and social events such as "For a Beautiful City", "For Home Improvement", etc. These actions fit well with the ideology of American pragmatism and egalitarianism (equality). His eloquent illustration is the statement of B. Franklin: "The beauty of what is useful should become the basis of the aesthetics of the young republic" and "... one school teacher is worth a dozen poets, and the new machine is more important than Raphael's masterpieces". In the same spirit, the philosopher and psychologist J. Dewey understood the purpose of aesthetics and the meaning of art classes. Considering art in his concept of aesthetic education from a purely utilitarian perspective, he reduced his acquaintance with it to the tasks of forming practical skills and abilities to do convenient things $[1, \mathrm{p} .56]$.

\section{Main part (methods)}

The idea of usefulness was the basis of the ideology and practical activities of art museums that opened in New York, Boston, Philadelphia and Chicago. In this sense, the experience of the Toledo Museum of Art, which involved citizens in city improvement work, organized didactic exhibitions of models of houses, interiors, suburban areas and even disseminated recommendations on gardening with the sale of seeds, is very remarkable. On his initiative, the "Bird Club" was created, in the framework of which schoolchildren raised and cared for birds in city parks, which became a clear example of attracting children to a useful cause.

At the same time, each museum in one way or another pursued purely educational goals, and in some of them the post of "museum teacher" (Boston Museum of Art) was specifically introduced. Thus, since 1890 the Detroit Museum of Art has carried out extensive educational work in the field of visual arts, archeology, literature, and various branches of science. The indicated museum also created various kinds of societies and associations - the "Society of Women Artists", "the Association of Library Workers", etc., which testified to its direct pedagogy and to the transformation of the museum into a kind of educational institution.

The most convex educational goals were identified in the Charter of the largest art museum in the United States - the Metropolitan Museum of Art (New York). Founded in 1870 with the aim of developing and 
studying fine arts, applying them in production and practical life, as well as for the development of art education, it is a unique alloy of influences, primarily from English and German museums. Today, the Metropolitan became a model of the American Museum both in the vastness and quality of collections, and in the scale and variety of forms of working with the audience (excursions, concerts, lectures, movie screenings, guidebooks) $[2,89$ p.].

In 1893, an international congress on the teaching of art was held in Chicago in the framework of the World Columbian Exhibition, which also exhibited works of art. The usefulness of numerous exhibitions of industrial art was also considered here. In 1907, the Society for the Promotion of Industrial Education was created in the USA, and in 1910 a conference was held in Boston on the development of industrial design. A peculiar result of these actions was the holding, nine years later, by the Metropolitan Museum of Art (in its department of education the industrial arts sector was allocated) a grand exhibition that demonstrated achievements in this area.

However, the education of good taste was an equally important task for the art museum. At the same time, a unique type of museum was formed in American culture, in which historical and technical monuments are presented to the visitor in the context of various areas of human activity. This is the National Museum of History and Technology in Washington (founded in 1904) with truly boundless collections reflecting the development in the United States over two hundred years of science (archeology, astronomy, history), politics, industry, transport, visual arts, military affairs, etc.

Works of art became an indispensable component of American museums not by chance: this was consistent with the ideology of the aesthetic movement, which proclaimed art and beauty as a counterbalance to industrialist materialism. Already at the beginning of the XX century US museums were regarded not only as symbols of national prestige, but also as a means of aesthetic education. "Greatness and glory come to the nation when the cult of art becomes the highest authority," proclaims R. Weier, director of the Huxley Gallery of Art and publisher of Aesthetics magazine [3, 96 p.].

In the concern for the formation of artistic taste, museums begin to organize lecture concerts, free visits to their expositions and travel to them by public transport. But what is especially important, the process of conceptual understanding of this kind of activity begins.

One of the first theorists of the educational function of the American Museum was a follower of D. Ruskin and South Kensington School D. Goodd, who saw the goal of museums in teaching ideas through objects. Drawing a line between art and science museums, the researcher considered the study of the museum collection to be an initial contribution to education, speaking out for providing the viewer with the necessary written information - leaflets, guides and monographs about artists. He also advocated holding public lectures. D. Goodd's initiatives were quickly implemented. Already in 1906, the first guidebook was introduced in the Metropolitan Museum, introducing visitors to the exposition, and a manual for teachers. On weekends, lectures were given to the public. A special "Metropolitan Bulletin" was devoted to museum education, where they discussed the development of various programs for all categories of visitors, including public lectures for the "general public", students, teachers, designers, and even for the blind and deaf. In 1919, the attention of the specialists of this museum was attracted to work in primary and secondary schools and in other educational institutions.

Pedagogical museums were more characteristic of Russia, where they were organized on the initiative of public education bodies, and various kinds of educational societies, which until 1917 were about a thousand. Other departments interested in good professional training of their personnel did not stand aside from this.

Further we consider the functions of the pedagogical museum on the example of the oldest pedagogical museum of military schools not only in Russia but also in Europe. Founded in 1864 in St. Petersburg as an educational institution of extra-departmental significance, it was conceived with the aim of developing urgent problems of pedagogical science. Here is how the specifics of a museum of this profile was determined by one of its directors, Maksheyev: "Pedagogical museums should not have the character of a Kunstkamera at all - in front of them lies a different road. To follow the theoretical and practical movement in the field of training and education, to concentrate, if possible, on everything worthy of attention in the field of visual training and, systematizing this material, give the modern teacher the opportunity to get acquainted with the technical means of his profession (devices , maps, models, paintings, etc.)

The museum's collections were divided into three groups: school manuals, manuals on the study of man as a subject of upbringing, and manuals on out-of-school education. Initially, they were represented by one permanent exhibition, but then, with the accumulation of a large number of exhibits in each of the class- 
rooms representing specialized disciplines (history, mathematics, drawing, natural sciences, physics, native language, experimental psychology), only some samples of collections were shown.

The museum took an active part in the production of school visual aids, and it was engaged in publishing, in conducting temporary courses for teachers of the native and foreign languages, geography, natural sciences and drawing, training officers-educators for a year and teachers of cadet corps for two years, in participating in the organization of pedagogical congresses. In concern for the aesthetic education of Petersburgers, the museum organized a folk choir and generally accessible music classes. The first psychological laboratory in Russia worked here [4, 123 p.].

In this list of cases for the benefit of society it is necessary to highlight the participation of this museum in Russian and foreign exhibitions of textbooks. Their geography extended from St. Petersburg to Paris, Brussels to Philadelphia and Chicago. Of particular importance was the success at the 1875 World's Fair in Paris. It was dedicated to the Geographical Congress, after which similar museums were opened in France and Belgium. By the end of the XIX century only in European countries, the leaders among which were Germany and England, there were about 70 such museums.

Along with pedagogical ones school museums were widespread as well. Having appeared in large numbers at the turn of the 19th - 20th centuries, they were brought to life by the need to teach children to extract knowledge both from direct observation of the surrounding life, and from objects collected in the school museum, which was "a necessary gathering of collections, devices, paintings, and in general of all that is daily used by a school where visual teaching is introduced ... "Such museums were the property of lower-level schools that oriented their pupils to work, and the main principle of their complement was the usefulness of the subject for acquaintance with reality. It is not by chance that preference was given to local history subjects in school museums, and the whole school took part in the collection of exhibits, which allowed not only to acquaint students with the specifics of life of a particular locality in all its manifestations, but also to establish creative relationships between the teacher and students at school. In general, under the name "school museum" most often meant visual, often completed or collected by students, material intended for demonstration in the classroom. Interest in school museums was shown not only by teachers, but also by prominent scientists, public figures, who created manuals and guides for organizing such museums and advocated the organization of methodological centers on the basis of the best museums. In order to better use visual material in the educational process, they recommended distributing the museum's collection into sections of humanitarian and natural science knowledge $[5,75 \mathrm{p}$.$] .$

\section{Discussion}

Currently, the system of supplementary education for schoolchildren is going through a period of formation. Lacking mandatory state requirements, it is endowed with the right to independently determine the meanings and values of its activities, based on the interests of children and taking into account state standards of general education.

The main tasks of the supplementary education system is to create conditions for organizing and carrying out cultural leisure of children outside school hours by introducing into the educational process: active and activity technologies of teaching and upbringing, creating an emotionally attractive environment for engaging in a particular type of activity, a psychologically comfortable atmosphere of interaction as well as the availability of good material equipment of the educational process and professional creative teachers " $[5,56$ p.].

Supplementary education organizations provide children with the opportunity to develop special creative abilities, such as scientific, cognitive, musical, artistic, acting skills.

But at present, there is a tendency to increase the number of learners, who are not enrolled anywhere other than school. It should be noted that the chances of developing their creative abilities in children who do not attend supplementary education organizations are even lower. There are quite a few reasons that contributed to the creation of such a social situation, this is the financial situation of parents, a lack of parental attention and disinterest of children, as well as the lack of interaction between educational organizations and organizations of supplementary education.

Studying the scientific literature and articles on the problem of interaction between general and supplementary education, it can be stated that this problem is relevant at the present time.

Self-realization of the personality of a learners occurs in a certain environment and interaction with different objects (things, etc.), people, that is, in a certain environment. The state of the external environment can have both a stimulating and a depressing effect on the self-realization of a learner's personality. 
An environment that promotes self-expression, revealing the potential of a person increases the effectiveness of self-realization and vice versa. This means that the creation of a creative environment in an institution of additional education will contribute to the disclosure of the personal potential of a teenager.

Supplementary education is a special type of education, an environment that has great opportunities in terms of personal development, meeting its needs, interests, creates conditions for creative self-realization in a variety of activities: art, technology, physical education, choreography, ecology, music and so on.

Interest in researching the problems of supplementary education for children has grown significantly in the last decade. Supplementary education of children is considered by scientists not only as the provision of additional services that go beyond the limits of compulsory basic education, but also as an environment for adolescents to solve personally significant goals and objectives, organize leisure time, choose a circle of friends, choose life values and guidelines for self-development, creative self-realization and professional self-determination.

The purpose of this interaction is to unite the efforts of the school and the organization of additional education in upbringing and education, expanding and developing the cognitive and scientific capabilities of students, pedagogical education, organizing and directing the activities of public and extracurricular organizations to actively participate in the educational process, and provide assistance to the family and school. Considering the fact that modern children read little, spend a lot of time at computers, gadgets, they observe limited interaction with the wide world of nature, it becomes necessary to take children out of school - to organize a system of interaction between an educational institution and municipal scientific institutions. Younger schoolchildren should actively visit science museums and science centers.

\section{Result}

Concluding a brief analysis of the educational activities of museums in different historical stages, we note that in connection with the domination; ideology of pragmatism contributed to the transformation of the museum into pedagogical institution. We impose 3 ways of joint work of museum as a supplementary educational institution and school:

1. Cultural (for the most prepared visitors).

2. Educational: a) to provide professional level in arts and crafts; b) to provide school education tasks and related practical purposes.

3. Recreational - rest and entertainment in a museum environment.

Thus, on the basis of theoretical understanding in museums, the socio-cultural function of the museum and the directions of its educational activities were determined.

Educational activities of museums have had a certain impact on the development of similar processes in neighboring countries, with the difference that the museum business began to develop in developing countries several decades later and did not reach the same level as in developed countries.

The interest in the revival of the school museum that has been observed in recent years should give it a new impetus for development, taking into account the potential possibilities of its pedagogical impact on teachers and children.

The experience gained in the USA in working with visitors made it possible to concretize tasks that can be considered typical, but with an emphasis on the specifics of the art museum: "The museum should create conditions for the education of children, conditions for healthy recreation and the accumulation of adult knowledge. It should be a repository from which the student draws knowledge, and a source of inspiration for the artist. Its influence should be felt in the house and reflected in the life of all members of society."

Having analyzed the work of museums in American society we can say that museums provided with a powerful infrastructure for servicing visitors, they do not impose strict rules on them in leisure and familiarization with art. For the first time, this function was designated by a student of D. Goodd A. Parker, who, considered the museum as a social institution connected with life and modern values, came to the conclusion that his visit is a certain type of organized vacation.

\section{Conclusion}

Thus, the educational activity of a modern museum should be considered in three aspects - cognitive, creative and social. Each of them, being closely related to others, reflects a certain content of museum work in this direction. The school museum, in many respects being a sphere of children's creative work, not only raised students' interest in the world around them, but also useful skillswere formed. It was also a means of maintaining that high professional level of a teacher who, according to Russian tradition, made him a con- 
noisseur and mentor in the eyes of those around him. In Soviet times, school museums, having lost the majority of their former purpose, turned into a formal reflection of the history of the school and the achievements of its leadership, although the school museum should be a reflection of the content and quality of life of the stuff,- the center of museum-pedagogical and regional studies integrated into the educational process work. The interest in the revival of the school museum that has been observed in recent years should give it a new impetus for development, taking into account the potential possibilities of its pedagogical impact on teachers and children.

\title{
References
}

1 Столяров Б.А. Музейная педагогика. История, теория, практика / Б.А. Столяров. - М.: Высш. шк., 2004. - С. 25.

2 Юхневич М.Ю. Педагогические, школьные и детские музеи дореволюционной России: метод. пос. / М.Ю. Юхневич. — М.: Высш. шк., 1990. - С. 184.

3 Ed. N. Berry and S. Mayer. Museum Education: History, theory and Practice. — Reston, 2005. — S. 86.

4 Чумбалова Г.М. К вопросу о формировании у студентов компетенции саморазвития / Г.М. Чумбалова, 3.К. Кокенова // Вестн. Казах. нац. мед. ун-та. - 2014. - № 3. - С. 73.

5 Lacoe J, Painter GD, Williams D. Museums as Classrooms: The Academic and Behavioral Impacts of "School in the Park.” AERA Open. July 2020. doi:10.1177/2332858420940309

\author{
Ян. Данек, Б.К. Шаушекова, Е.С. Ибраева
}

\section{Мектептің қосымша білім беру ұйымдарымен бірлестік жұмысының әр түрлі тарихи кезеңдердегі ерекшеліктері}

\begin{abstract}
Мақалада музей мен мектептің ежелгі ғасырлардан қазіргі уақытқа дейінгі өзара әрекеті қарастырылды. Авторлар дамыған елдердегі мұражайлар мен мектептердің бірлескен жұмысын егжей-тегжейлі сипаттайды және олардың осындай ынтымақтастықты жүргізудегі тәжірибелерін талдаған. Мақалада мұражай мен мектептің өзара әрекеттесу мәселелері және әр түрлі тарихи кезеңдердегі өзара әрекеттестіктің ерекшеліктері келтірілген. Авторлар ынтымақтастықтың перспективалық үлгілерін сипаттайды және «мұражай мен мектеп» мәселесі шетелде қалай шешіледі? деген сұраққа жауап береді. Мұражайлардың студенттермен жұмысы егжей-тегжейлі талқыланған, яғни мектеп жасына дейінгі балалармен және кіші, орта және жоғары сынып оқушыларымен жұмыс. Бастауыш мектеп жасындағы оқушылармен қосымша білім беруді ұйымдастыру тәжірибесінің ерекшеліктері де толық сипатталған. Авторлар білім беру ұйымдарының мұражайларын жіктеген: университет мұражайлары, мектеп мұражайлары және педагогикалық мұражайлар. Сонымен қатар педагогикалық мұражайлардың даму және өркендеген кезеңдерін; педагогикалық мұражайлардың, тарихи-өлкетану мұражайларының, балалар мұражайларының эволюциясын зерттеген. АҚШ пен Ресейдегі педагогикалық мұражайлардың артықшылықтары да қарастырылған және мұражай мен мектеп арасындағы серіктестіктің болашағын атап өткен.
\end{abstract}

Кілт сөздер: мұражай, мектеп, оку мұражайлары, мектеп мұражайлары, өзара әрекеттесу, мекемелердің өзара әрекеті, оку ортасы, оку процесі.

\section{Ян Данек, Б.К. Шаушекова, Е.С. Ибраева}

\section{Особенности совместной работы школы с организациями дополнительного образования на разных исторических этапах}

В статье рассмотрено взаимодействие музея и школы с ранних веков до наших дней. Авторами подробно описана совместная работа музеев и школ в развитых странах и проанализирован их опыт ведения такого сотрудничества. Перечислены проблемы взаимодействия музея и школы и особенности взаимодействия на разных исторических этапах. Авторы, предлагая перспективные модели сотрудничества, пытаются найти ответы на вопрос: «Как решается проблема музея и школы за рубежом?». Работа музеев со студентами подробно обсуждалась, то есть работа с дошкольниками, младшими, средними и старшими школьниками. Изучены особенности опыта работы организации дополнительного образования с учащимися младшего школьного возраста. Авторы дали классификацию музеев образовательных учреждений: университетских, школьных и педагогических музеев. Кроме того, рассмотрены педагогические музеи в период зарождения и процветания, эволюции педагогических музе- 
ев, музеев истории образования и детских музеев; отмечены преимущества педагогических музеев в США и России и дальнейшие перспективы партнерства музея и школы.

Ключевые слова: музей, школа, образовательные музеи, школьные музеи, взаимодействие учреждений, учебная среда, учебный процесс.

\section{References}

1 Stolyarov, B.A. (2004). Muzeinaia pedahohika. Istoriia, teoriia, praktika [Museum pedagogics. History, theory, practice]. Moscow: Vyshchaia shkola [in Russian].

2 Jukhnevich, M.Yu. (1990). Pedahohicheskie, shkolnye i detskie muzei dorevoluitsionnoi Rossii [Pegagogical, school and children museums of pre-revolutional Russia]. Moscow: Vysshaiia shkola [in Russian].

3 Berry, N., \& Mayer, S. (Eds.). (2005). Museum Education: History, theory and Practice. Reston.

4 Chumbalova, G.M., \& Kokenova, Z.K. (2014). K voprosu o formirovanii u studentov kompetentsii samorazvitiia [On issue of formation of self-development competence of students]. Vestnik Kazakhskoho natsionalnoho universiteta - Bulletin of the Kazakh National University, 3 [in Russian].

5 Lacoe J, Painter GD, Williams D. Museums as Classrooms: The Academic and Behavioral Impacts of "School in the Park.” AERA Open. July 2020. doi:10.1177/2332858420940309 